\title{
Analysis of TOEIC Scores of State Bengkalis Politechnic Students in Institutional TOEIC Training
}

\author{
Ari Satria \\ Politeknik Negeri Bengkalis \\ email: arisatria@polbeng.ac.id
}

\begin{abstract}
In improving students' English competence, Bengkalis State Polytechnic holds TOEIC Institutional training for students who have obtained TOEIC scores above 400 for diploma three and 450 for diploma four. Students must have a good English certificate in order to continue their studies, scholarships and apply for work. This study was conducted to determine whether there are differences in TOEIC scores in Institutional TOEIC Training for students between classes A, B and C. Data analysis was done by Anova using SPSS version 22. The population in this study was 60 students. The results of this study indicate that student learning outcomes or TOEIC scores in the Institutional TOEIC Training between class A, class $\mathrm{B}$ and class $\mathrm{C}$ are significantly different.
\end{abstract}

Keywords: TOEIC, training, comparison

\section{INTRODUCTION}

Bengkalis State Polytechnic uses the Test of English for International Communication (TOEIC) test as a standard score to measure English language skills, both diploma three and diploma four students. For students who have obtained TOEIC scores above 400 for diploma three and 450 for diploma four, Bengkalis State Polytechnic provides Institutional TOEIC training for eight meetings and provides scholarships for the TOEIC Institutional test in collaboration with PT. ITC Jakarta.

Institutional TOEIC training for students is one program to improve students' ability in English competence through the TOEIC test both listening and reading. This ELT-Lectura, Vol 7, No 1, February 2020 training material is standardized from ETS questions and is given tricks and tips in answering questions in a short time.

Obstacles commonly experienced by students are in listening and reading. To get good score in both listening and reading, students are required to listen and read a lot of the latest news both from the mass media and online, because the TOEIC test forms are Listening and Reading.

There are some previous researches, first, Fauziati (2016) conducted "Analisis Pertanyaan pada Butir Soal Reading Comprehension pada Test TOEIC." This research is aimed to obtain a comprehensive description on aspects related to the TOEIC test items, as follows: (1) the question pattern 
of Completion and Error Recognition section; (2) the context of reading text in Reading Comprehension section; (3) the pattern of the question on reading Comprehension section; (4) the frequency of each type of question in Reading section. The scope of this study is the TOEIC model test, especially the structure and reading section. The data consists of 500 test items taken from TOEIC preparation books published by Barron's Educational Series, Prentice Hall, and Longman. Data collection techniques used in this study is documentation techniques. The data analysis technique used is descriptive interpretative. The results are as follows: (1) the linguistic components questioned in the Completion and Error recognition section include vocabulary (54.34\%), Class of words (15\%), Verb tense $(11.33 \%)$, determiner $(5.33 \%)$ preposition (4\%), conjunction $(3.67 \%)$, degree of comparison in adjective (3.33\%), and conditional sentence (3\%); (2) Context of reading text in Reading Comprehension section covers business, manufacturing, finance and budgeting, Offices, personnel, purchasing, housing, travel, dining out, entertainment, and Health; (3) aspects questioned in Reading Comprehension section include: (a) the main idea and the possibility of proper title, (b) the information is written in the text, (c) information between the lines, (d) and the purpose of writing. Based on the results, it is concluded that mastery of vocabulary is essential for success in the TOEIC test since it occupies 50\% of the test.

Second, Satria dan Zahraa (2018) conducted The Factors Affect TOEIC
Passing Grades In TOEIC Intensive Course For Third Year Students. This study is expected to provide an overview of the factors that affect TOEIC Passing Grades in TOEIC Intensive Course for Final Year Students. The purpose of this study is to conduct an empirical investigation whether the internal factor variable and external factors affect the variable of passing grade. The total populations in this study were 150 respondents. The data were collected through questionnaires. Data analysis was done by multiple regression using SPSS version 22. The result showed that internal factor had an effect on student's learning achievement, while external factor had no influence to the TOEIC passing grades.

Third, Aisyiyah (2015) conducted a study on Self Esteem Analysis and Student Perception in English Language on English Language Ability Students of Jember State Polytechnic Superior Program. The study intends to examine whether there is an effect of student self esteem and perception on English both partially and jointly on the English language skills of Jember State Polytechnic students. This research data was collected using a questionnaire for independent variables, and the international TOEIC test for the dependent variable of 50 samples taken randomly. The data obtained were analyzed descriptively and inferentially. From the data analysis, the following results were obtained: (1) there was no effect of self esteem on students' English proficiency, (2) there was a significant influence on students' perceptions of students' English proficiency, (3) there was a significant influence together- 
the same as students 'self-esteem and perceptions of students' English proficiency.

Test of English for International Communication (TOEIC) consists of 200 multiple choices questions to determine everyday English skills and includes two language skills, namely listening (listening), and reading (reading). The Listening Test is first on the TOEIC paper and pencil test. The Listening Test consists of four parts and 100 questions total. The Listening Test lasts 45 minutes. The participant cannot go back during any of the four parts and listen again, and participant cannot go back between the parts or at the end.

Photographs : :10 questions

Question-Response : 30 questions

Short Conversations : 30 questions (10 conversations with 3 questions)

Short Talks : 30 questions (10 talks with 3 questions)

The Reading Test is second on the TOEIC paper and pencil test. The Reading Test consists of three parts and 100 questions total. The Reading Test lasts 75 minutes. Because the reading material is in the test booklet, the participant can go back to check or adjust the answers during the Reading Test.

Incomplete Sentences $\quad: 40$ questions

Text Completion : 12 questions

Reading Comprehension : 48 questions (Lougheed, 2006)

The TOEIC score range is 10-990 which is discribed by ETS in six levels:
1. Level 0/0+ Novice (score 10-250)

2. Level 1 Elementary (score 255-400)

3. Level 1+ Intermediate (score 405-600)

4. Level 2 Basic Working Proficiency (score 605-780)

5. Level 2+ Advance Working Profiency (score 785-900)

6. Level 3/3+ General Professional Proficiency (score 905-990).

\section{METHOD}

The method of this research is a descriptive research. The data collected was in the form of TOEIC scores of Bengkalis State Polytechnic students. The data are in the form of student final grades in the TOEIC Institutional Training for students.

\section{Population}

This study analyzes the student's final TOEIC score in the Intensive TOEIC Training for students. The population in this study is 60 students. All populations are sampled.

\section{Variable}

This study aims to prove whether there are differences in sores in studying TOEIC between classes $\mathrm{A}, \mathrm{B}$ and $\mathrm{C}$. The variables used in this study are only one variable, the final value of the Student TOEIC. The final value is a combination of Listening and Reading scores.

\section{Analysis}

Data analysis was carried out, using the help of a SPSS computer program version 
22. Data processing used, Anova testing tools.

The testing hypothesis for the Homogeneity of variances test is:

H0: The third variance class of TOEIC score is the same

H1: The variance of the three classes of TOEIC score is not the same

For testing criteria are:

- If the probability or significance> 0.05 then $\mathrm{HO}$ is accepted

- If the probability or significance $<0.05$ then $\mathrm{H} 0$ is rejected.

For the Anova test, the decision making criteria are:
-H0: the average TOEIC value of the three classes is the same

$-\mathrm{H} 1$ : the average TOEIC value of the three classes is not the same

(Sarwono, 2012)

\section{FINDINGS AND DISCUSSION}

\section{Descriptive Analysis}

This study was conducted to determine whether there are differences in TOEIC scores in Institutional TOEIC Training for students between classes A, B and C. Descriptive test results are presented in Table 1. Descriptive

Nilai

\section{Descriptives}

\begin{tabular}{|c|c|c|c|c|c|c|}
\hline \multirow[b]{2}{*}{ N Mean } & \multirow{2}{*}{$\begin{array}{c}\text { Std. } \\
\text { Deviation }\end{array}$} & \multirow{2}{*}{$\begin{array}{l}\text { Std. } \\
\text { Error }\end{array}$} & Mean & $\begin{array}{l}\text { ce Interval for } \\
\text { an }\end{array}$ & \multirow{2}{*}{\multicolumn{2}{|c|}{ Minimum Maximum }} \\
\hline & & & Lower Bound & Upper Bound & & \\
\hline Kelas A 20456.00 & 8.697 & 2.821 & 418.70 & 493.30 & 350 & 610 \\
\hline Kelas B 20423.50 & 6.808 & 1.597 & 395.04 & 451.96 & 330 & 520 \\
\hline Kelas C 20433.50 & 4.714 & 1.669 & 411.17 & 455.83 & 340 & 520 \\
\hline 60437.67 & 6.476 & 1.324 & 421.01 & 454.32 & 330 & 610 \\
\hline Based or & & $J_{1}$ & & 1.916 & 57 & 143 \\
\hline
\end{tabular}

TOEIC score for class $\mathrm{A}$ is 456 higher than the score of class B which is 423.50 and class $\mathrm{C}$ is 433.50. That is, the highest average TOEIC score is in class A, while the lowest average TOEIC score is in class B.

Test of Homogeneity

Table 2. Test of Homogeneity

Test of Homogeneity of Variances

Nilai

Levene

Statistic df1 df2
To test variance similarity, hypothesize with the following sounds:

H0: The third variance class of TOEIC value is the same

H1: The variance of the three classes of TOEIC values is not the same

Seeing the results of the Levene Statistics figures at the above output amounted to 1.916 with a significance / 
probability (sig) of 0.143 . Use the following criteria:

- If the probability or significance> 0.05 then $\mathrm{HO}$ is accepted

- If the probability or significance $<0.05$ then $\mathrm{H} 0$ is rejected.

Test of Anova

Table 3. Test of Anova

\begin{tabular}{|c|c|c|}
\hline \multicolumn{3}{|c|}{ ANOVA } \\
\hline & Sum of Squares df & an Square $\mathrm{F}$ \\
\hline Between Groups & 11083.3332 & 5541.6674 .140 .010 \\
\hline Within Groups & 234190.00057 & 4108.596 \\
\hline Total & 245273.33359 & \\
\hline
\end{tabular}

Because the significance / probability of the calculation results from observational data is 0.143>0.05, $\mathrm{H} 0$ is accepted; $\mathrm{H} 1$ rejected. So, since $\mathrm{HO}$ is accepted, the conclusion is that the three variance classes of TOEIC scores compared are the same. 
Hypothesis:

-H0: the average TOEIC value of the three classes is the same

-H1: the average TOEIC value of the three classes is not the same

Looking at the calculated $\mathrm{F} / \mathrm{Fo}$ number of 4.140 , for $n 1: 3-1=2$, and $n 2$ : $60-3=57$, the $\mathrm{F}$ table number with the above conditions is 3.16

Decision: because the calculated $\mathrm{F}$ number falls in the rejection area, then $\mathrm{H} 0$ is rejected and $\mathrm{H} 1$ is accepted.

It can be concluded that the average TOEIC score of the three classes is different. Thus, the average TOEIC grades of class A, $\mathrm{B}$ and $\mathrm{C}$ are significantly different.

\section{CONCLUSION}

This study was conducted to determine whether there are differences in TOEIC scores in TOEIC Institutional Training between classes $\mathrm{A}, \mathrm{B}$ and $\mathrm{C}$. The results of this study indicate that student learning outcomes or grades in TOEIC Institutional Training between classes A, class B and class $\mathrm{C}$ are significantly different.

\section{REFERENCES}

Aisyiyah, S. (2015). Analisis Sef Esteem Dan Persepsi Mahasiswa Pada Bahasa Inggris Terhadap Kemampuan Berbahsa Inggris Mahasiswa Program Unggulan Politeknik Negeri Jember. Jurnal Ilmiah INOVASI, Vol. 15 No.1,
Hal. 33-40, Januari -April 2015, ISSN 1411-5549

Fauziati, E. (2016). Analisis Pertanyaan pada Butir Soal Reading Comprehension pada Test TOEIC. Jurnal Penelitian Humaniora, 17(1), 922.

International Test Center. (2017). Tentang TOEIC. Diperoleh dari http://itcindonesia.com/index.php/id/2013-1014-18-37-51/k2-categories/item/1-toeic

Lougheed, L. (2004). How to Prepare for the TOEIC Test, 3rd Edition. Jakarta: Binarupa Aksara.

(2006). Longman Preparation Series for the New TOEIC Test: Introductory Course (with Answer Key), with Audio CD and Audioscript (4th Edition). USA: Longman.

Oxford University Team. (2002). Oxford Preparation Course for the TOEIC Test. New York: Oxford University Press.

Sarwono, J. (2012). Mengenal SPSS Statistics 20; Aplikasi untuk Riset Eksperimental. Jakarta: PT. Ale Media Komputindo

Satria, A,. and Zahraa. 2018. The Factors Affect TOEIC Passing Grades in TOEIC Intensive Course for Final Year Students. Inovish Journal, Vol. 3, No. 2, December 2018 from http://ejournal.polbeng.ac.id/index.php/I $\mathrm{J} /$ article/view/808 